Article

\title{
Evaluation of Polyethylene Mulching and Sugarcane Cultivar on Energy Inputs and Greenhouse Gas Emissions for Ethanol Production in a Temperate Climate
}

\author{
Takahiro Nakashima ${ }^{1, *(\mathbb{D}) \text {, Keiichiro Ueno }}{ }^{2, \dagger}$, Eisuke Fujita ${ }^{2, \ddagger}$ and Shoko Ishikawa $1, * \mathbb{D}$ \\ 1 Central Region Agricultural Research Center, National Agriculture and Food Research \\ Organization (NARO), 2-1-18 Kannondai, Tsukuba, Ibaraki 305-8666, Japan \\ 2 Kumage Branch, Kagoshima Prefectural Institute for Agricultural Development, Nishinoomote, \\ Kagoshima 891-3101, Japan; ueno-keiichirou@pref.kagoshima.lg.jp (K.U.); \\ e-fujita@pref.kagoshima.lg.jp (E.F.) \\ * Correspondence: tnakasim@affrc.go.jp (T.N.); shokoish@affrc.go.jp (S.I.) \\ + Present address: Kagoshima Prefectural Institute for Agricultural Development, 2200 Ono Kinpo-Cho, \\ Minamisatsuma, Kagoshima 899-3401, Japan. \\ $\ddagger$ Present address: Aira Isa Area Promotion Bureau, 12 Kajiki-Cho Suwamachi, Aira, Kagoshima \\ 899-5212, Japan.
}

Received: 3 July 2020; Accepted: 20 August 2020; Published: 24 August 2020

\begin{abstract}
Fossil energy inputs and greenhouse gas (GHG) emissions associated with the cultivation and transport of sugarcane (Saccharum officinarum) for bioethanol production in Tanegashima, Japan, were estimated by life cycle assessment (LCA). The aim was to understand the effects of combined systems of polyethylene mulching treatment (mulching at planting and every ratooning, MM; mulching only at planting, MU; and untreated, i.e., no mulching at all, UU) and cultivar (a cold-tolerant genotype, NiTn18, and a conventional variety, NiF8). The mulch treatments and cultivars were combined to create six cultivation systems that were used to conduct a comparative assessment of cradle-to-gate energy inputs and emissions for bioethanol production. The LCA results showed that the energy inputs and GHG emissions resulting from the MM/NiF8 system were $6.29 \mathrm{MJ} \mathrm{L}^{-1}$ and $0.500 \mathrm{~kg} \mathrm{CO}_{2} \mathrm{e} \mathrm{L}^{-1}$, which were $14 \%$ and $23 \%$ lower, respectively, than the corresponding values in the UU/NiF8 system. In contrast, the MU/NiF8 system increased the environmental loads slightly. The use of NiTn18 improved sugarcane performance and ethanol yields substantially as compared with NiF8, reducing energy inputs to 5.38, 5.24, and 5.55 MJ L $\mathrm{L}^{-1}$ and GHG emissions to $0.473,0.450$, and $0.441 \mathrm{~kg} \mathrm{CO}_{2} \mathrm{e} \mathrm{L}^{-1}$ for the UU, MU, and MM treatments, respectively. The energy inputs and GHG emissions were similar among the systems, indicating that more flexible mulching treatments might be acceptable in the NiTn18 systems than in the NiF8 systems. The energy inputs and GHG emissions resulting from the UU/NiTn18 system were 14\% and $5 \%$ lower, respectively, than those of the MM/NiF8 system, suggesting that it may be possible to overcome the handicap of sugarcane production in cold conditions by breeding cold-tolerant cultivars.
\end{abstract}

Keywords: life cycle assessment; sugarcane; bioethanol; energy inputs; greenhouse gas emissions; polyethylene mulch; cold tolerance

\section{Introduction}

Because of increased concern about global warming and its impacts on human civilization, biofuels have attracted attention as a means to mitigate anthropogenic greenhouse gas (GHG) emissions caused 
by intensive fossil fuel consumption and land use [1,2]. Sugarcane (Saccharum officinarum) is one of the promising feedstock crops for bioethanol production and can be grown in a wide range of tropical and subtropical regions with considerable amounts of precipitation [3]. Useful substrates such as sucrose, glucose, and fructose that can be directly fermented without the need for saccharification to ethanol are produced from sugarcane $[4,5]$. In addition, sugarcane-derived bioethanol co-generates bagasse (the fibrous residue remaining after the extraction of juice from the crushed stalks of sugarcane), which can play a crucial role in the conversion process of sugarcane to ethanol by providing thermal energy and electricity [5]. As in other parts of the world, pursuing a stable supply of low-cost biofuel is a stated goal of the Japanese government in agriculture [6]. Although Brazil has been able to successfully convert a considerable amount of its petroleum consumption to sugarcane-derived bioethanol $[7,8]$, at least part of their success must be attributed to local climate conditions. It is desirable to establish a sugarcane cultivation system suitable for bioethanol production in a less-favorable, i.e., colder climate.

Backed by a sugar mill, Tanegashima $\left(30^{\circ} 44^{\prime} \mathrm{N}, 131^{\circ} 00^{\prime} \mathrm{E}\right)$ is generally considered to be the northern limit of the sugarcane production area in Japan [9]. From 1981 to 2010, the annual average atmospheric temperature in Tanegashima $\left(19.6^{\circ} \mathrm{C}\right)$ did not appear very different from that in São Paulo, Brazil $\left(20.0^{\circ} \mathrm{C}\right)$, while the difference between summer and winter temperatures was wider in Tanegashima due to the lower temperature in winter and early spring [10]. The occurrence of frost is quite common during the early germination period of sugarcane in this area [9]. Low temperatures and cold weather-related incidents have adverse effects on stalk growth and sugar accumulation in sugarcane, as observed in so-called cool sugarcane-growing areas such as Louisiana (USA) and Tucumán (Argentina). Nonetheless, sugarcane farmers in Tanegashima have achieved average yields as high as $73.6 \mathrm{Mg} \mathrm{ha}^{-1}$ year ${ }^{-1}$ over the past decade [11], partly because of intensive farming practices, including polyethylene mulching [9]. The beneficial effects of polyethylene mulching for sugarcane growth have already been reported in China, India, and South Africa as well as Japan [12-16]. Ebata et al. [12] observed that the soil temperature beneath the polyethylene film during the early germination period of sugarcane in Tanegashima was $4-10^{\circ} \mathrm{C}$ higher than the fields that had no mulch, indicating that polyethylene mulching allowed earlier planting. Yasuniwa et al. [14] reported that polyethylene mulch increases stalk yields by $15-30 \%$ in this region. Polyethylene mulching is therefore regarded as a measure to alleviate the adverse effects of low temperature for sugarcane growth, and it has been applied to more than half of the plant cane fields in Tanegashima [11]. According to sugarcane cultivation guidelines in this region, farmers should mulch both at planting and ratooning [17].

However, the use of polyethylene film for sugarcane production requires additional fossil energy inputs during the field operations related to mulching as well as in the synthesis of the material used. It also affects GHG emissions from the on- and off-farm processes related to polyethylene mulching, for example, those resulting from changes in fuel and material consumption. Thus, to assess the environmental impacts of polyethylene mulching for sugarcane production, the processes related to crop production must be considered in an all-inclusive manner. Life cycle assessment (LCA) $[18,19]$ has contributed greatly in this area, and it has been shared among researchers that sugarcane-derived bioethanol in major producing countries, mostly situated at low latitudes, has an environmental advantage in terms of fossil energy consumption and GHG emission as compared with other crop-derived biofuels such as sugar beet, maize, and wheat [20-24]. In a recent LCA study, Nakashima and Ishikawa [25] showed that an average sugarcane producer in Tanegashima, Japan, can viably produce energy, but they pointed out a need to reconsider agronomic options, including the practice of polyethylene mulching, to enhance the energy-efficiency of the sugarcane-based bioethanol production system. As an alternative to polyethylene mulching, they suggested the possibility of introducing new cultivars/varieties characterized by excel early phase growth sometimes expressed as early vigor, which is an important trait, especially in cool climates [26,27]. The objective of the present LCA study was to estimate fossil energy consumption and GHG emissions in various cultivation systems of sugarcane to compare the effects of three polyethylene mulching treatments and two cultivars (a cold-tolerant genotype, NiTn18; a conventional variety, NiF8). Life cycle inventories (LCIs) 
of sugarcane cultivation, transportation, and ethanol yields were developed using data collected from field experiments conducted in Tanegashima, Japan.

\section{Materials and Methods}

\subsection{Field Experiment}

To determine the stalk yield and yield-related components of sugarcane in different treatments of mulching and cultivars, three field experiments were conducted at the Kumage Branch $\left(30^{\circ} 43^{\prime} \mathrm{N}\right.$, $131^{\circ} 79^{\prime}$ E) of the Kagoshima Prefectural Institute for Agricultural Development in Tanegashima from 2003 to 2009 (see Tables A1 and A2). At planting, two-bud sets of sugarcane cultivars NiF8 and NiTn18 were planted with a row space of $1.2 \mathrm{~m}$ and an inter-hill space of $0.3 \mathrm{~m}$. The size of each plot consists of three rows of $5.1 \mathrm{~m}$ length (experiment 1 ) and four rows of $5.1 \mathrm{~m}$ length (experiments 2 and 3 ). The cultivation scheme was four times in 4 years: one plant cane and three ratoons. The soil is a well-drained soil of volcanic origin (Andosol), representative of the region. NiF8, a conventional cultivar, has been commonly grown in Tanegashima since its release in 1992 by the Tanegashima Experimental Station currently known as the Tanegashima Sugarcane Breeding Site, Kyushu Okinawa Agricultural Research Center, National Agriculture and Food Research Organization (NARO). NiTn18 is an alternative cultivar characterized by an improved yielding ability and cold tolerance during the period of early germination [28].

Except for the treatments, field practices followed the local recommendation for sugarcane production both on plant cane and ratoons [17]. Before planting, cattle manure (moisture content of $50 \%$ and $1.0 \%$ of $\mathrm{N}$ concentration were assumed) was applied at a rate of $20 \mathrm{Mg} \mathrm{ha}^{-1}$ and incorporated into the soil using a plow and harrow powered by a wheel tractor. Fertilizer was applied using bulk blending fertilizer mixing different types such as ammonium sulphate, ammonium phosphate and potassium chloride. At basal dressing, $70 \mathrm{~kg} \mathrm{ha}^{-1}$ of N, $120 \mathrm{~kg} \mathrm{ha}^{-1}$ of $\mathrm{P}_{2} \mathrm{O}_{5}$, and $60 \mathrm{~kg} \mathrm{ha}^{-1}$ of $\mathrm{K}_{2} \mathrm{O}$ were applied; $80 \mathrm{~kg} \mathrm{ha}^{-1}$ of $\mathrm{N}$ and $60 \mathrm{~kg} \mathrm{ha}^{-1}$ of $\mathrm{K}_{2} \mathrm{O}$ were added as a top dressing. Weed management was a combination of herbicide application and mechanical weed control by inter-row tillage (hereafter, intertillage) powered by a wheel tractor. Pest control against major pests such as sugarcane wireworm (Melanotus spp.) and oriental chinchi bug (Cavelerius saccharivorus) followed the standard methods used in the region and included the application of two types of insecticides in the present study.

\subsubsection{Treatments for Mulching}

At planting, the field experiment was designed as a split-plot of two factors with cultivar being the main plot and mulch treatment being the sub plot replicated three times (experiment 1 ) and twice (experiments 2 and 3) (Table A1). Mulching treatment consists of three ways of applying mulch, (1) mulching at planting and every ratooning (MM), (2) mulching only at planting (MU), and (3) untreated, i.e., no mulching at all (UU) (Table 1).

Table 1. Polyethylene mulch treatments for sugarcane production in field experiments.

\begin{tabular}{ccccc}
\hline Treatment & Plant Cane & 1st Ratoon & 2nd Ratoon & 3rd Ratoon \\
\hline MM & $\sqrt{ }$ & $\sqrt{ }$ & $\sqrt{ }$ & $\sqrt{ }$ \\
MU & $\sqrt{ }$ & & & \\
UU & & & &
\end{tabular}

$\mathrm{MM}$, mulching at planting and every ratooning; $\mathrm{MU}$, mulching only at planting; UU, untreated, i.e., no mulching at all. $\sqrt{ }$, treated with mulch.

At harvest, the crop was manually removed from one row of $4.5 \mathrm{~m}$ length (experiment 1 ) and two rows of $4.5 \mathrm{~m}$ length (experiments 2 and 3). A series of ratooning operations were conducted using a stubble shaver and a root cutting plow, details of which can be found elsewhere [25]. A $0.02 \mathrm{~mm}$ thick transparent film [17] was applied with a mulcher pulled by a hand tiller. The width of the film was 
$0.45 \mathrm{~m}$ and $0.60 \mathrm{~m}$ for plant cane and ratoons, respectively. The applied polyethylene mulch was torn with a hand knife once the nursery cane grew enough beneath the film; it was then removed from the fields before intertillage prior to disposal.

\subsubsection{Measurement and Statistical Analysis}

Fresh-basis stalk yield (SY, Mg ha ${ }^{-1}$ ), brix in juice (BJ, \%) and fiber yield (FY, $\mathrm{Mg} \mathrm{ha}^{-1}$ ) were examined on harvest samples of both plant cane and ratoons. A shredder KS-MS (Matsuo Co., Ltd., Kagoshima, Japan) and a hydraulic press machine KS-OP (Matsuo Co., Ltd., Kagoshima, Japan) were used to prepare the samples for measurements, and BJ was determined with a Brix meter DBX-55 (Atago Co., Ltd., Tokyo, Japan). Total sugar (TS, $\mathrm{Mg} \mathrm{ha}^{-1}$ ) and ethanol yield ( $\mathrm{kL} \mathrm{ha}^{-1}$ ) were estimated as follows [29-31]:

$$
\begin{gathered}
\mathrm{TS}=(\mathrm{SY}-\mathrm{FY}) \times \mathrm{BJ} / 10^{2}, \\
\text { Ethanol yield }=\mathrm{TS} \times\left(\mathrm{T}_{\mathrm{c}} / 10^{2}\right) \times\left(\mathrm{P}_{\mathrm{c}} / 10^{2}\right) / \mathrm{D}_{\mathrm{e}},
\end{gathered}
$$

where $\mathrm{T}_{\mathrm{c}}$ is a theoretical conversion efficiency from sugar to ethanol (51\%), $\mathrm{P}_{\mathrm{c}}$ is a practical conversion efficiency $(90 \%)$, and $\mathrm{D}_{\mathrm{e}}$ is the density of ethanol $\left(0.806 \mathrm{~kg} \mathrm{~L}^{-1}\left[20^{\circ} \mathrm{C}\right]\right)$. The SPSS statistical program (IBM) was used to analyze the results. Analysis of variance (ANOVA) was performed on SY, BJ, FY and TS, and effects of treatments were evaluated by mean comparisons with the Scheffé method. All of the significant results are referred to at the 5\% level unless otherwise specified. Ethanol yield was treated as the key variable to link the field experiments and environmental assessment described in the next section.

\subsection{Life Cycle Assessment}

Data collected from the field experiment described in Section 2.1 were used to estimate fossil energy consumption and GHG emissions in the various cultivation systems.

\subsubsection{System Description}

The goal of the LCA was to estimate fossil energy consumption and GHG emissions in sugarcane cultivation systems to understand the effects of alternative treatments of mulching (i.e., treatments MM, MU, and UU) and cultivars (i.e., NiF8 and NiTn18). Six cultivation systems were generated to comparatively assess the cradle-to-gate energy inputs and emissions within the system boundary, with the functional unit being $1 \mathrm{~L}$ of anhydrous ethanol produced (Figure 1). Energy inputs and GHG emissions associated with sugarcane production are also reported on an area (ha) basis following the common practice in agricultural research.

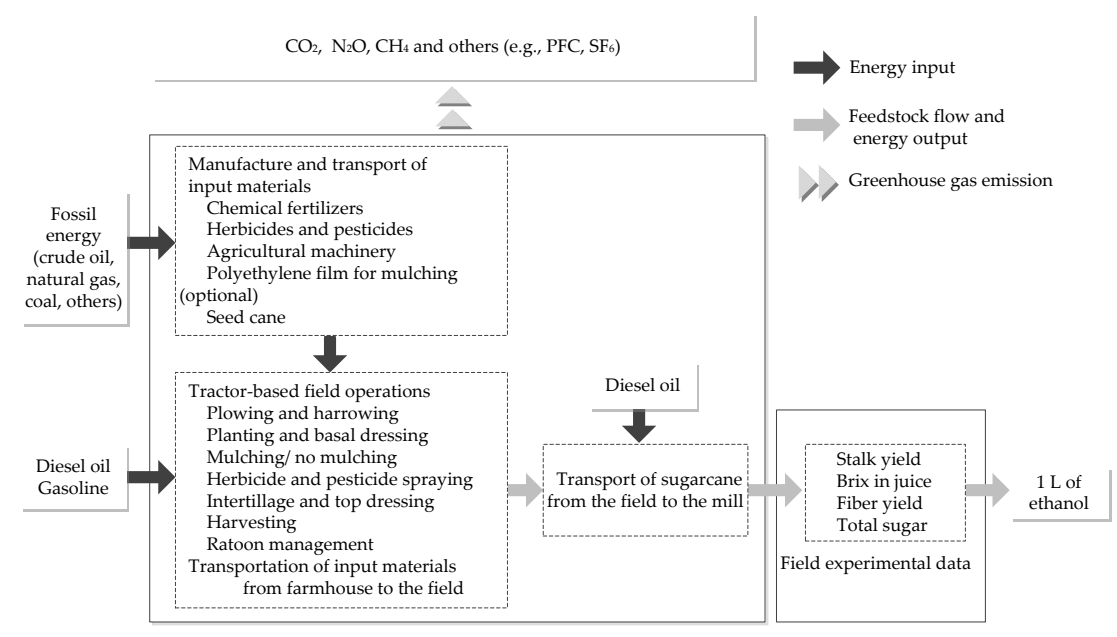

Figure 1. System boundary of sugarcane cultivation and transportation for bioethanol production in the study area. 


\subsubsection{Life Cycle Inventory}

We compiled LCIs of overall fossil energy inputs, material inputs, and GHG emissions associated with each sugarcane production process. The energy inputs and GHG emissions were estimated by multiplying fuel/material consumption by energy equivalents as well as emission factors, respectively. The energy equivalents and emission factors for fuel/material consumption were adopted from the Inventory Database for Environmental Analysis [32,33], which is frequently used in LCA studies in the field of agriculture in Japan (e.g., $[25,34,35])$. Diesel oil and gasoline consumption $\left(\mathrm{L} \mathrm{ha}^{-1}\right)$ for tractor/tiller-based field operations were computed on the basis of fuel efficiency $\left(\mathrm{L} \mathrm{hr}^{-1}\right)$ and work efficiency $\left(\mathrm{hr} \mathrm{ha}^{-1}\right)$ data collected from other field experiments and supplemented by other published results (e.g., [25]).

Assuming that fuel consumption during harvest from the use of a self-propelled chopping harvester depended on SY $\left(\mathrm{Mg} \mathrm{ha}^{-1}\right)$, we calculated the diesel oil consumption for harvest, $\mathrm{D}_{\mathrm{h}}\left(\mathrm{L} \mathrm{ha}^{-1}\right)$ :

$$
D_{h}=E_{h} \times S Y,
$$

where $E_{\mathrm{h}}$ is the fuel efficiency of harvester (1.63 $\mathrm{L} \mathrm{Mg}^{-1}$ of canes; [25]).

Assuming a $15 \mathrm{~km}$ one-way distance from the fields to the mill, diesel oil consumption in a round-trip truck transport (total $30 \mathrm{~km}$ ) of sugarcane $\left(\mathrm{D}_{\mathrm{t}}, \mathrm{L} \mathrm{ha}^{-1}\right)$ was calculated as follows:

$$
\mathrm{D}_{\mathrm{t}}=\left(30 / \mathrm{E}_{\mathrm{f}}\right) \times(\mathrm{SY} / 10)
$$

where $E_{\mathrm{f}}$ is the fuel efficiency $\left(3.5 \mathrm{~km} \mathrm{~L}^{-1}\right)$ of a $10 \mathrm{Mg}$ (load capacity) truck [36]. Diesel oil consumption for the transport of input materials (e.g., chemical fertilizers and polyethylene film) between the farmhouse and fields by truck (load capacity of $2.0 \mathrm{Mg}$ ) were also considered.

The amount of chemical fertilizer, agrochemicals (e.g., herbicides and pesticides), and agricultural machinery were adopted primarily from the local recommendations for sugarcane production [17], supplemented by information obtained in interviews with sugarcane farmers and breeders. The amount of polyethylene film used for mulching $\left(\mathrm{m}^{3} \mathrm{ha}^{-1}\right)$ was calculated on the basis of the length, width, and thickness of the material applied. The total length of the film was calculated to reflect a row space of $1.2 \mathrm{~m}$ (Section 2.1.1). The energy consumption and GHG emission amounts related to seed cane were taken from Nakashima and Ishikawa [25].

Soil-associated emissions of $\mathrm{N}_{2} \mathrm{O}$ resulting from the application of fertilizers and manure under aerobic conditions were also considered. The level of $\mathrm{N}$ inputs was $150 \mathrm{~kg} \mathrm{~N}^{-1}$ year $^{-1}$ for chemical fertilizers, and the $\mathrm{N}$ concentration of the manure applied before planting was assumed to be $1.0 \%$ on a fresh matter basis. Emission factors for soil emissions were taken, as in the previous study [25], from the 2006 IPCC Guidelines for National Greenhouse Gas Inventories [37], except for direct $\mathrm{N}_{2} \mathrm{O}$ emissions from nitrification-denitrification processes. For readers' convenience, the emission factor is listed here to be $0.62 \%$ (the percentage of $\mathrm{N}_{2} \mathrm{O}-\mathrm{N}$ out of the applied $\mathrm{N}$ ) for direct $\mathrm{N}_{2} \mathrm{O}$ emission. This is the average value reported for upland soils in Japan [38,39]. Indirect emissions of $\mathrm{N}_{2} \mathrm{O}$ considered in the present study supposedly occurred through atmospheric deposition, $\mathrm{N}$ leaching, and run-off to water [37].

\subsubsection{Life Cycle Impact Assessment and Sensitivity Analysis}

Life cycle impact assessment (LCIA) was performed to evaluate potential environmental impacts from cultivation system involving mulching and cultivar. The inventory data were sorted and assigned to the two midpoint impact categories of cumulative fossil fuel demand and global warming; they were then multiplied by characterization factors to be aggregated in each group. The characterization factors of global warming were adopted from the $\mathrm{CO}_{2}$-equivalent global warming potential (GWP) for a 100-year time horizon. For example, the $\mathrm{GWP}_{100}$ of $\mathrm{N}_{2} \mathrm{O}$ and $\mathrm{CH}_{4}$ were reported to be 298 and 25 times greater than that of $\mathrm{CO}_{2}$, respectively [40]. After performing the LCIA, we conducted a 
sensitivity analysis to test the effects of variation in two parameters (number of ratoons and the direct $\mathrm{N}_{2} \mathrm{O}$ emission factor for mulched soil) on the comparative LCA results.

\section{Results and Discussion}

\subsection{Stalk Yield and Yield-Related Components}

The mean values of SY, BJ, FY, and TS are presented in Table 2. An interaction was observed in SY and TS between cultivar and mulching for the total (plant cane plus the three ratoons averaged on a yearly basis). Mulching treatments significantly improved SY and TS of NiF8, but the effect was less apparent with NiTn18. SY of NiF8 was the greatest in the MM plots, confirming that there were beneficial effects of mulching both at planting and ratooning. The plots treated with mulch at planting performed rather poorly in the following ratoon unless mulch was reapplied; this was especially true with NiF8, where SY was smaller in the MU plots on ratoons than it was in the UU plots (Table 2). The under-performance of the crop in the MU plots might be an example of "stress imprint effects", a term explained by Bruce et al. [41] as "a genetic or biochemical modification of a plant that occurs after stress exposure that causes future responses to future stresses to be different". Even though a question arises about how long the priming effects could last, it is interesting that Bruce et al. [41] mentioned cases of seed priming and even transgenerational stress imprint effects. As to BJ and FY, no interaction was observed between cultivar and mulching (Table 2). FY was significantly affected by cultivar and mulching, whereas although BJ did increase in the plots treated with mulch, none of the differences were statistically significant. With plant cane, Ebata et al. [12] also observed an increased BJ for the plots treated with mulch as compared to untreated plots at some locations in Kagoshima Prefecture, Japan. They attributed the increased brix of mulched plots to a greater share of early sprouted stalks to harvested stalks as compared to the share in untreated plots. Unlike SY and FY, it is likely that one cannot always expect significant and positive effects of mulching on BJ.

\subsection{Energy Inputs and GHG Emissions from Fuel and Agricultural Materials}

On-farm energy inputs during sugarcane cultivation and transportation totaled 7.77-11.6 GJ ha ${ }^{-1}$ year $^{-1}$ (Table 3), and the corresponding GHG emissions were $0.561-0.837 \mathrm{Mg} \mathrm{CO}_{2} \mathrm{e} \mathrm{ha}^{-1}$ year $^{-1}$ (Table 4). As is shown in Table 3, the greatest amount of the on-farm energy was required for the harvest (3.28-5.57 GJ ha ${ }^{-1}$ year $\left.^{-1}\right)$, followed by transport of sugarcane to the mill (1.73-2.93 GJ ha ${ }^{-1}$ year $\left.^{-1}\right)$; the sum of these two amounted to $64.0-73.6 \%$ of total on-farm energy consumption, indicating energy intensiveness of the processes. The rest of the energy was spent in tillage $\left(0.812 \mathrm{GJ} \mathrm{ha}^{-1} \mathrm{year}^{-1}\right)$,

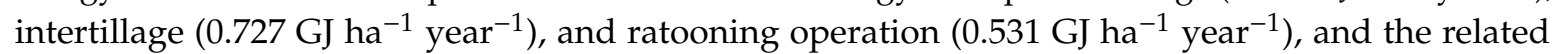
GHG emissions were incurred correspondingly. Field operations for mulching required a relatively small amount of fuel energy consumption $\left(0.0813 \mathrm{GJ} \mathrm{ha}^{-1}\right.$ year $^{-1}$ for MU and $0.325 \mathrm{GJ} \mathrm{ha}^{-1}$ year $^{-1}$ for $\mathrm{MM})$. However, it is obvious that the mulch treatments increased energy consumption during sugarcane harvest and transportation by increasing SY (Table 3).

Material-related off-farm energy inputs for sugarcane production totaled 24.2-29.8 GJ ha ${ }^{-1}$ year $^{-1}$ (Table 3), and the corresponding GHG emissions were 1.38-1.54 $\mathrm{Mg} \mathrm{CO}_{2} \mathrm{e} \mathrm{ha}^{-1}$ year $^{-1}$ (Table 4). For all three mulch treatments, the synthesis of fertilizers (15.0 GJ ha ${ }^{-1}$ year $^{-1}$ ) required the most energy, followed by the manufacture of agricultural machinery $\left(5.20 \mathrm{GJ} \mathrm{ha}^{-1}\right.$ year $\left.{ }^{-1}\right)$. For treatment MM only, $5.52 \mathrm{GJ} \mathrm{ha}^{-1}$ year $^{-1}$ was required during the synthesis of polyethylene film used for mulching because mulch is required at both planting and ratooning. In a recent LCA of an "average" cultivation system of sugarcane in Tanegashima, Japan, Nakashima and Ishikawa [25] reported a relatively small amount of off-farm energy consumption for polyethylene mulching (1.48 GJ ha ${ }^{-1}$ year $\left.^{-1}\right)$. 
Table 2. ANOVA and multiple comparisons by the Scheffé method performed on harvest data of plant cane and three ratoons.

\begin{tabular}{|c|c|c|c|c|c|c|c|c|c|c|c|c|c|c|c|c|c|c|c|c|}
\hline \multirow{2}{*}{ Cultivar/Mulching } & \multicolumn{4}{|c|}{ Plant Cane } & \multicolumn{4}{|c|}{ 1st Ratoon } & \multicolumn{4}{|c|}{ 2nd Ratoon } & \multicolumn{4}{|c|}{ 3rd Ratoon } & \multicolumn{4}{|c|}{ Total $^{4}$} \\
\hline & $\mathrm{SY}^{3}$ & BJ & FY & TS & SY & BJ & FY & TS & SY & BJ & FY & TS & SY & BJ & FY & TS & SY & BJ & FY & TS \\
\hline \multicolumn{21}{|l|}{ NiF8 ${ }^{1}$} \\
\hline $\mathrm{MM}^{2}$ & 73.0 & 16.5 & 7.6 & 10.7 & 75.9 & 17.2 & 8.4 & 11.6 & 77.5 & 18.5 & 8.7 & 12.5 & 61.8 & 19.2 & 8.2 & 10.3 & 71.6 & 17.9 & 8.2 & 11.2 \\
\hline MU & 73.0 & 16.5 & 7.6 & 10.7 & 45.7 & 16.9 & 5.0 & 6.9 & 46.7 & 18.4 & 5.5 & 7.6 & 34.7 & 18.8 & 4.2 & 5.7 & 50.5 & 17.6 & 5.6 & 7.8 \\
\hline UU & 55.4 & 16.2 & 5.5 & 7.9 & 51.4 & 16.9 & 5.6 & 7.9 & 51.9 & 18.3 & 6.3 & 8.5 & 40.7 & 18.8 & 5.1 & 6.7 & 49.9 & 17.6 & 5.6 & 7.7 \\
\hline \multicolumn{21}{|l|}{ NiTn18 } \\
\hline MM & 91.0 & 16.7 & 11.3 & 13.2 & 97.2 & 17.9 & 14.2 & 14.8 & 86.9 & 19.3 & 13.6 & 14.0 & 66.1 & 19.4 & 10.9 & 10.7 & 84.6 & 18.3 & 12.5 & 13.1 \\
\hline MU & 91.0 & 16.7 & 11.3 & 13.2 & 87.7 & 17.3 & 12.0 & 13.1 & 78.4 & 18.5 & 11.4 & 12.3 & 56.6 & 19.2 & 8.9 & 9.1 & 79.2 & 17.9 & 10.9 & 12.1 \\
\hline UU & 76.8 & 16.3 & 9.0 & 10.9 & 81.7 & 17.4 & 11.1 & 12.2 & 76.6 & 18.7 & 11.8 & 12.1 & 57.8 & 19.3 & 9.2 & 9.4 & 73.2 & 18.0 & 10.3 & 11.2 \\
\hline Interaction & ns & ns & ns & ns & ns & ns & ns & ns & ns & ns & ns & ns & ns & ns & ns & ns & * & ns & ns & * \\
\hline Cultivar & $* * *$ & ns & $* * *$ & $* * *$ & $* * *$ & $*$ & $* * *$ & $* * *$ & $* * *$ & $*$ & $* * *$ & $* * *$ & $* *$ & $* *$ & $* * *$ & $* *$ & $* * *$ & $* *$ & $* * *$ & $* * *$ \\
\hline Mulch & $* * *$ & ns & $* * *$ & $* * *$ & $* *$ & ns & $* * *$ & $* * *$ & $* *$ & ns & $* * *$ & $* * *$ & $* *$ & ns & $* *$ & $* *$ & $* * *$ & $*$ & $* * *$ & $* * *$ \\
\hline
\end{tabular}

${ }^{1} \mathrm{NiF} 8$, a conventional cultivar; NiTn18, a new cultivar characterized by improved yielding capacity and cold tolerance. ${ }^{2}$ MM, mulching at planting and every ratooning; MU, mulching only at planting; UU, untreated, i.e., no mulching at all. ${ }^{3} \mathrm{SY}$, fresh-basis stalk yield $\left(\mathrm{Mg} \mathrm{ha}^{-1}\right)$; BJ, brix in juice $(\%)$; FY, fiber yield $\left(\mathrm{Mg}^{-1}\right)$ : $\mathrm{TS}$, total sugar $\left(\mathrm{Mg}^{-1}\right)=(\mathrm{SY}-\mathrm{FY}) \times$ $\left(\mathrm{BJ} / 10^{2}\right) .{ }^{4}$ Total, plant cane plus the three ratoons averaged on a yearly basis. ${ }^{* * *} p<0.001 ;{ }^{* *} p<0.01 ;{ }^{*} p<0.05 ; \mathrm{ns}$, not significant. 
Table 3. Energy inputs (GJ ha ${ }^{-1}$ year $^{-1}$ ) estimated for the combined cultivation systems of three polyethylene mulch treatments and two cultivars.

\begin{tabular}{|c|c|c|c|c|c|c|}
\hline \multirow{4}{*}{ Energy Input Source } & \multicolumn{6}{|c|}{ Sugarcane Cultivar } \\
\hline & \multicolumn{3}{|c|}{ NiF8 } & \multicolumn{3}{|c|}{ NiTn18 } \\
\hline & \multicolumn{6}{|c|}{ Mulching Treatment } \\
\hline & MM & MU & UU & MM & MU & UU \\
\hline \multicolumn{7}{|l|}{ On-farm energy inputs } \\
\hline Tractor-based field operations & 7.59 & 5.94 & 5.82 & 8.44 & 7.83 & 7.34 \\
\hline Manure application & 0.0493 & 0.0493 & 0.0493 & 0.0493 & 0.0493 & 0.0493 \\
\hline Tillage 1 & 0.812 & 0.812 & 0.812 & 0.812 & 0.812 & 0.812 \\
\hline Planting ${ }^{2}$ & 0.216 & 0.216 & 0.216 & 0.216 & 0.216 & 0.216 \\
\hline Mulching & 0.325 & 0.0813 & - & 0.325 & 0.0813 & - \\
\hline Intertillage $^{3}$ & 0.727 & 0.727 & 0.727 & 0.727 & 0.727 & 0.727 \\
\hline Insecticide spraying & 0.205 & 0.205 & 0.205 & 0.205 & 0.205 & 0.205 \\
\hline Harvesting & 4.72 & 3.32 & 3.28 & 5.57 & 5.21 & 4.80 \\
\hline Ratooning 4 & 0.531 & 0.531 & 0.531 & 0.531 & 0.531 & 0.531 \\
\hline Truck transport of input materials & 0.250 & 0.227 & 0.220 & 0.250 & 0.227 & 0.220 \\
\hline Truck transport of sugarcane & 2.48 & 1.75 & 1.73 & 2.93 & 2.74 & 2.53 \\
\hline Subtotal (A) & 10.3 & 7.92 & 7.77 & 11.6 & 10.8 & 10.1 \\
\hline \multicolumn{7}{|l|}{ Off-farm energy inputs } \\
\hline Fertilizers & 15.0 & 15.0 & 15.0 & 15.0 & 15.0 & 15.0 \\
\hline Agrochemicals & 2.95 & 2.95 & 2.95 & 2.95 & 2.95 & 2.95 \\
\hline Agricultural machinery & 5.20 & 5.20 & 5.20 & 5.20 & 5.20 & 5.20 \\
\hline Polyethylene film for mulching & 5.52 & 1.11 & - & 5.52 & 1.11 & - \\
\hline Seed cane & 1.08 & 1.08 & 1.08 & 1.08 & 1.08 & 1.08 \\
\hline Subtotal (B) & 29.8 & 25.3 & 24.2 & 29.8 & 25.3 & 24.2 \\
\hline Total $(\mathrm{A}+\mathrm{B})$ & 40.1 & 33.2 & 32.0 & 41.4 & 36.1 & 34.3 \\
\hline
\end{tabular}

This smaller value is largely attributable to the actual rates of polyethylene mulching (i.e., $62 \%$ and $15 \%$ of all sugarcane fields are mulched for plant cane and ratoons, respectively), which were assigned as weighting factors to estimate the "average" amount of polyethylene film consumption for sugarcane production in the area. If the same weighting factors and two ratoons were assumed in the present study, the off-farm energy inputs associated with treatment MM would be $1.52 \mathrm{GJ} \mathrm{ha}^{-1}$ year $^{-1}$. With this in mind, we consider the off-farm energy inputs of treatment MM to be fairly consistent with the previously reported value.

Soil-associated $\mathrm{N}_{2} \mathrm{O}$ emissions owing to the application of fertilizers and manure were estimated to be $0.909 \mathrm{Mg} \mathrm{CO}_{2} \mathrm{e} \mathrm{ha}^{-1}$ year ${ }^{-1}$ (Table 4), a comparable but slightly higher level than the on-farm GHG emissions from fuel energy consumption. When both the on- and off-farm processes and soil-associated emissions are accounted, energy inputs from fuels and agricultural materials totaled 32.0-41.4 GJ ha ${ }^{-1}$ year $^{-1}$ and total GHG emissions were 2.85-3.29 $\mathrm{Mg} \mathrm{CO}_{2} \mathrm{e} \mathrm{ha}^{-1}$ year $^{-1}$. 
Table 4. Greenhouse gas emissions $\left(\mathrm{Mg} \mathrm{CO}_{2}\right.$ eq. ha ${ }^{-1}$ year $\left.^{-1}\right)$ estimated for the combined cultivation systems of three polyethylene mulch treatments and two cultivars.

\begin{tabular}{|c|c|c|c|c|c|c|}
\hline \multirow{4}{*}{ Greenhouse Gas Emission Source } & \multicolumn{6}{|c|}{ Sugarcane Cultivar } \\
\hline & \multicolumn{3}{|c|}{ NiF8 } & \multicolumn{3}{|c|}{ NiTn18 } \\
\hline & \multicolumn{6}{|c|}{ Mulching Treatment } \\
\hline & MM & MU & UU & MM & MU & UU \\
\hline \multicolumn{7}{|l|}{ On-farm energy inputs } \\
\hline Tractor-based field operations & 0.547 & 0.429 & 0.420 & 0.608 & 0.565 & 0.530 \\
\hline Manure application & 0.00360 & 0.00360 & 0.00360 & 0.00360 & 0.00360 & 0.00360 \\
\hline Tillage $^{1}$ & 0.0585 & 0.0585 & 0.0585 & 0.0585 & 0.0585 & 0.0585 \\
\hline Planting 2 & 0.0155 & 0.0155 & 0.0155 & 0.0155 & 0.0155 & 0.0155 \\
\hline Mulching & 0.0230 & 0.00575 & - & 0.0230 & 0.00575 & - \\
\hline Intertillage $^{3}$ & 0.0524 & 0.0524 & 0.0524 & 0.0524 & 0.0524 & 0.0524 \\
\hline Insecticide spraying & 0.0145 & 0.0145 & 0.0145 & 0.0145 & 0.0145 & 0.0145 \\
\hline Harvesting & 0.341 & 0.240 & 0.237 & 0.402 & 0.376 & 0.347 \\
\hline Ratooning 4 & 0.0383 & 0.0383 & 0.0383 & 0.0383 & 0.0383 & 0.0383 \\
\hline Truck transport of input materials & 0.0180 & 0.0164 & 0.0158 & 0.0180 & 0.0164 & 0.0158 \\
\hline Truck transport of sugarcane & 0.179 & 0.126 & 0.125 & 0.211 & 0.198 & 0.183 \\
\hline Subtotal (A) & 0.744 & 0.571 & 0.561 & 0.837 & 0.779 & 0.729 \\
\hline \multicolumn{7}{|l|}{ Off-farm energy inputs } \\
\hline Fertilizers & 0.673 & 0.673 & 0.673 & 0.673 & 0.673 & 0.673 \\
\hline Agrochemicals & 0.155 & 0.155 & 0.155 & 0.155 & 0.155 & 0.155 \\
\hline Agricultural machinery & 0.448 & 0.448 & 0.448 & 0.448 & 0.448 & 0.448 \\
\hline Polyethylene film for mulching & 0.161 & 0.0323 & - & 0.161 & 0.0323 & - \\
\hline Seed cane & 0.104 & 0.104 & 0.104 & 0.104 & 0.104 & 0.104 \\
\hline Subtotal (B) & 1.54 & 1.41 & 1.38 & 1.54 & 1.41 & 1.38 \\
\hline Soil-associated emissions (C) & 0.909 & 0.909 & 0.909 & 0.909 & 0.909 & 0.909 \\
\hline Total $(\mathrm{A}+\mathrm{B}+\mathrm{C})$ & 3.19 & 2.89 & 2.85 & 3.29 & 3.10 & 3.02 \\
\hline
\end{tabular}

\subsection{Total Energy Inputs and Total GHG Emissions to Produce 1 L of Ethanol}

In the sugarcane cultivation system where NiF8 was combined with treatment UU (hereafter referred to as the UU/NiF8 system), an estimated $4.39 \mathrm{~kL} \mathrm{ha}^{-1}$ year ${ }^{-1}$ of ethanol could be generated from the harvested crop (Figure 2). The ethanol yields were higher for all the other systems, but varied widely, ranging from $4.44 \mathrm{~kL} \mathrm{ha}^{-1}$ year $^{-1}$ in the MU/NiF8 system to $7.46 \mathrm{~kL} \mathrm{ha}^{-1}$ year $^{-1}$ in the $\mathrm{MM} / \mathrm{NiTn} 18$ system.

Total energy inputs and total GHG emissions during sugarcane cultivation and transportation to produce $1 \mathrm{~L}$ of ethanol are presented in Figure 3a,b, respectively. In the UU/NiF8 system, 7.29 MJ of energy was input and $0.649 \mathrm{~kg} \mathrm{CO} 2 \mathrm{e}$ of GHG emission was incurred per $1 \mathrm{~L}$ ethanol produced. Total energy inputs and total GHG emissions from fuel and agricultural materials were considerably higher in the MM/NiF8 system, mostly for the harvest and transport of sugarcane as well as the synthesis of polyethylene film used for mulching (Tables 3 and 4), but the increase in ethanol yield was more pronounced (Figure 2). As a consequence, total energy inputs and total GHG emissions to produce $1 \mathrm{~L}$ of ethanol were $6.29 \mathrm{MJ} \mathrm{L}^{-1}$ and $0.500 \mathrm{~kg} \mathrm{CO}_{2} \mathrm{e} \mathrm{L}^{-1}$; these values are $14 \%$ and $23 \%$ lower, respectively, than those of the UU/NiF8 system (Figure 3a,b). This same result was not found for the $\mathrm{MU} / \mathrm{NiF} 8$ system. Because of the poor performance of ratoons (see Section 3.1), the increase in ethanol yield was insufficient to compensate for the increased total energy inputs and GHG emissions from fuel and agricultural materials. The cradle-to-gate energy inputs and GHG emissions were very similar (7.48 $\mathrm{MJ} \mathrm{L}^{-1}$ and $0.651 \mathrm{~kg} \mathrm{CO}_{2} \mathrm{e} \mathrm{L}^{-1}$, respectively) to those of the UU/NiF8 system. The adoption of 
NiTn18 improved ethanol yields substantially for all three mulch treatments as compared with NiF8, by $45 \%, 53 \%$, and $17 \%$ for treatment UU, MU, and MM, respectively (Figure 2). This led to 5.38, 5.24, and $5.55 \mathrm{MJ} \mathrm{L}^{-1}$ of energy inputs and $0.473,0.450$, and $0.441 \mathrm{~kg} \mathrm{CO}_{2} \mathrm{e} \mathrm{L}^{-1}$ of GHG emissions in the respective UU/NiTn18, MU/NiTn18, and MM/NiTn18 systems (Figure 3a,b).

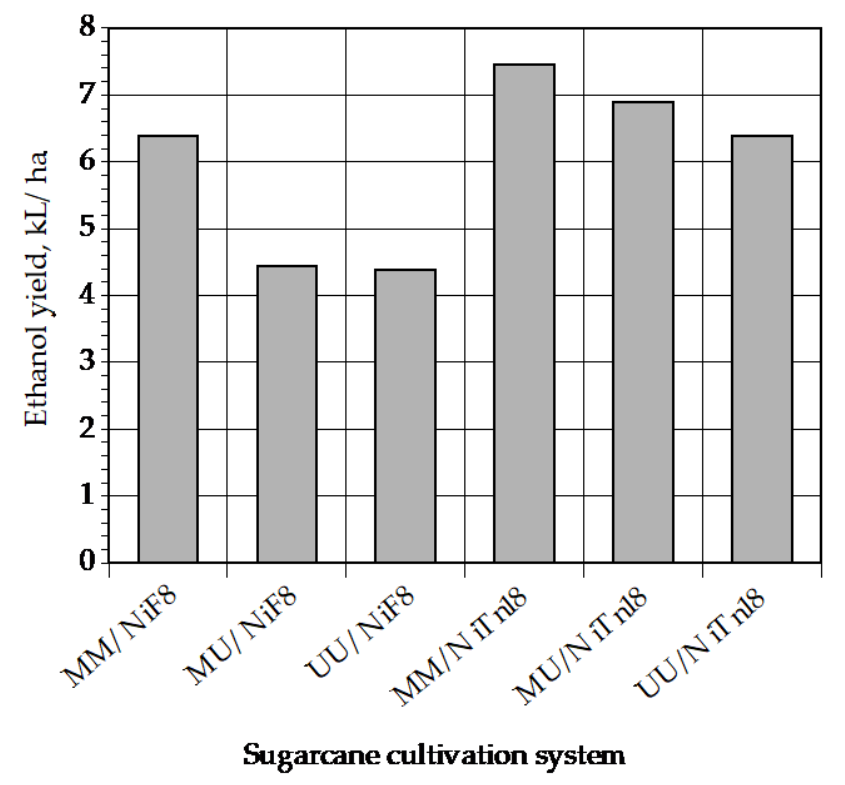

Figure 2. Ethanol yields estimated for the combined cultivation systems of three polyethylene mulch treatments and two cultivars. MM, mulching at planting and every ratooning; MU, mulching only at planting; UU, untreated, i.e., no mulching at all. NiF8, a conventional cultivar; NiTn18, a cultivar characterized by improved yielding capacity and cold tolerance.

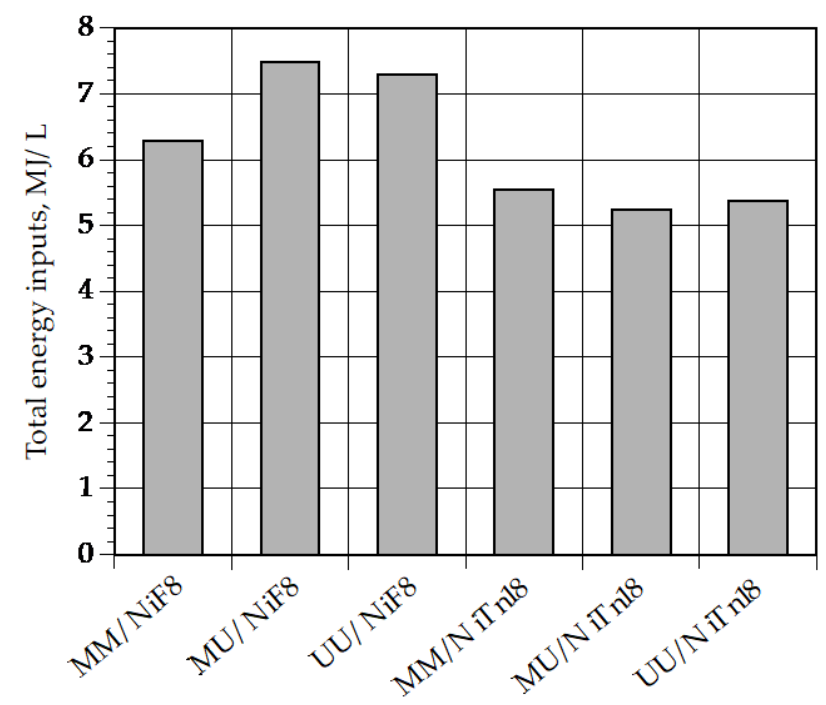

Sugarcane cultivation system

(a)

Figure 3. Cont. 


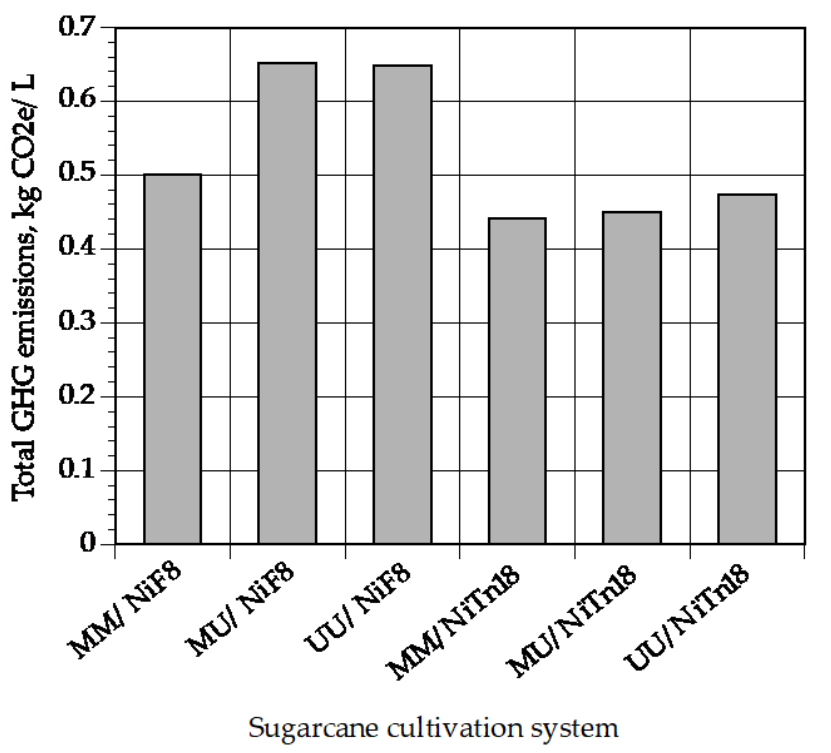

(b)

Figure 3. Total energy inputs (a) and total greenhouse gas (GHG) emissions (b) to produce $1 \mathrm{~L}$ of ethanol. MM, mulching at planting and every ratooning; MU, mulching only at planting; $\mathrm{UU}$, untreated, i.e., no mulching at all. $\mathrm{NiF8}$, a conventional cultivar; NiTn18, a cultivar characterized by improved yielding capacity and cold tolerance.

The results of the sensitivity analysis illustrated that the energy inputs and GHG emissions from sugarcane production were lower with two ratoons than with one ratoon (Figure $4 a, b$ ), partly because tillage and planting were conducted only once in the first year owing to the ratooning of sugarcane. Here, sugarcane cycle is defined as a sequence of plant cane (PC) and first, second, and third ratoons (R1, R2, R3) to facilitate the understanding of sensitivity analysis. Sugarcane cycle, PC-R1-R2 required less energy inputs for tillage and planting compared to PC-R1, implying some merits of taking ratoons twice instead of once. The performance of the third ratoon, however, was not good enough (Table 2) to improve the energy performance of sugarcane cycle PC-R1-R2-R3 compared to PC-R1-R2 (Figure 4a). This is in line with observations often made with sugarcane where yield of ratoons tends to decline with time [3] (pp. 22-23). Meanwhile, the comparative LCA results were valid, except for the case that the environmental advantage of the UU/NiF8 system over the MU/NiF8 system disappeared when the number of ratoons decreased to one or two as compared with the default value of three. The comparative LCA results for GHG emissions were sensitive to the direct $\mathrm{N}_{2} \mathrm{O}$ emission factor for mulched soil (Figure 5). This issue is addressed in Section 3.4. 

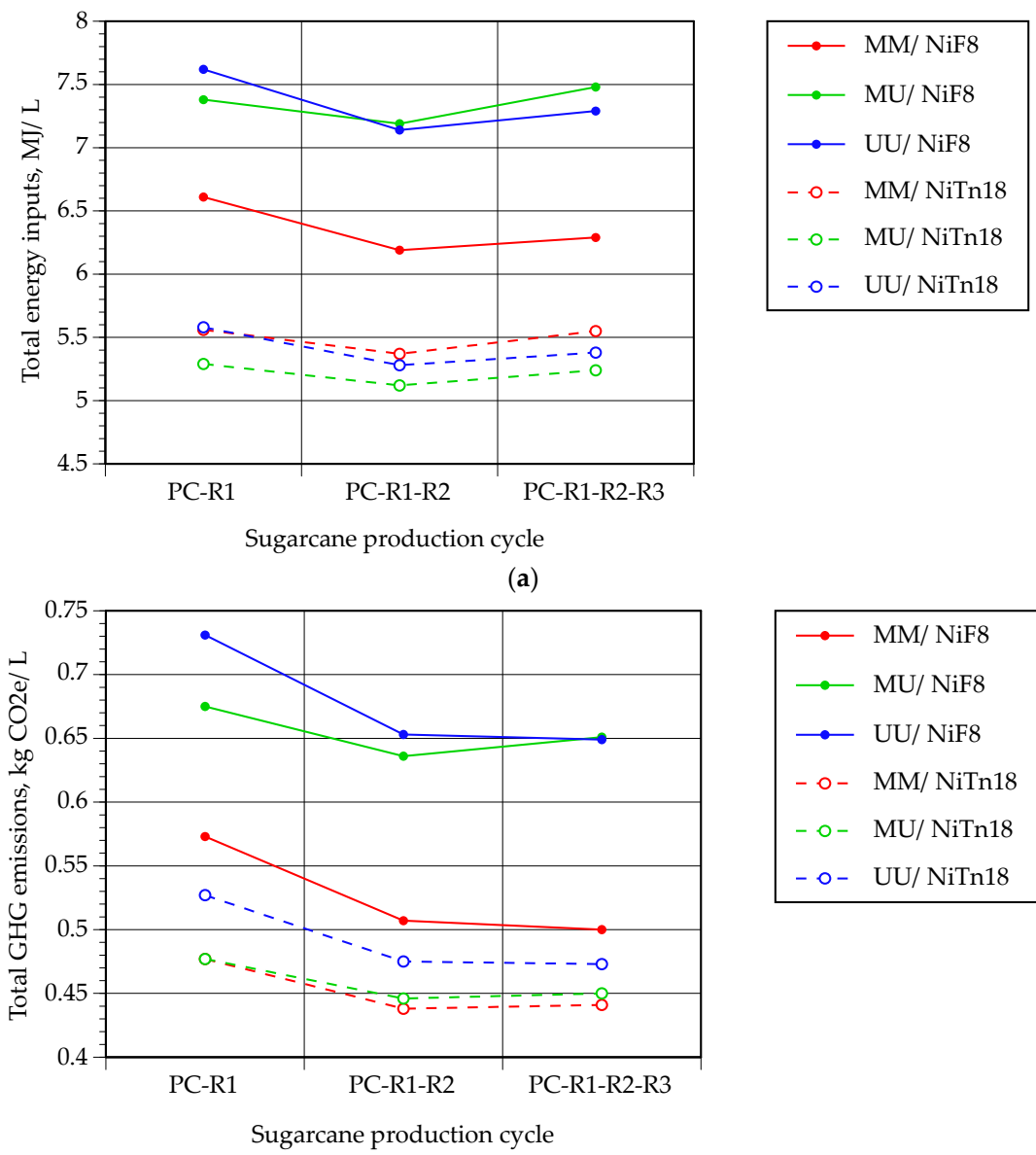

(b)

Figure 4. Sensitivity analysis of total energy inputs (a) and total greenhouse gas (GHG) emissions (b) to the number of ratoons. PC-R1, a plant cane and one ratoon; PC-R1-R2, a plant cane and two ratoons; PC-R1-R2-R3, a plant cane and three ratoons (the default scheme). MM, mulching at planting and every ratooning; $\mathrm{MU}$, mulching only at planting; $\mathrm{UU}$, untreated, i.e., no mulching at all. NiF8, a conventional cultivar; NiTn18, a cultivar characterized by improved yielding capacity and cold tolerance.
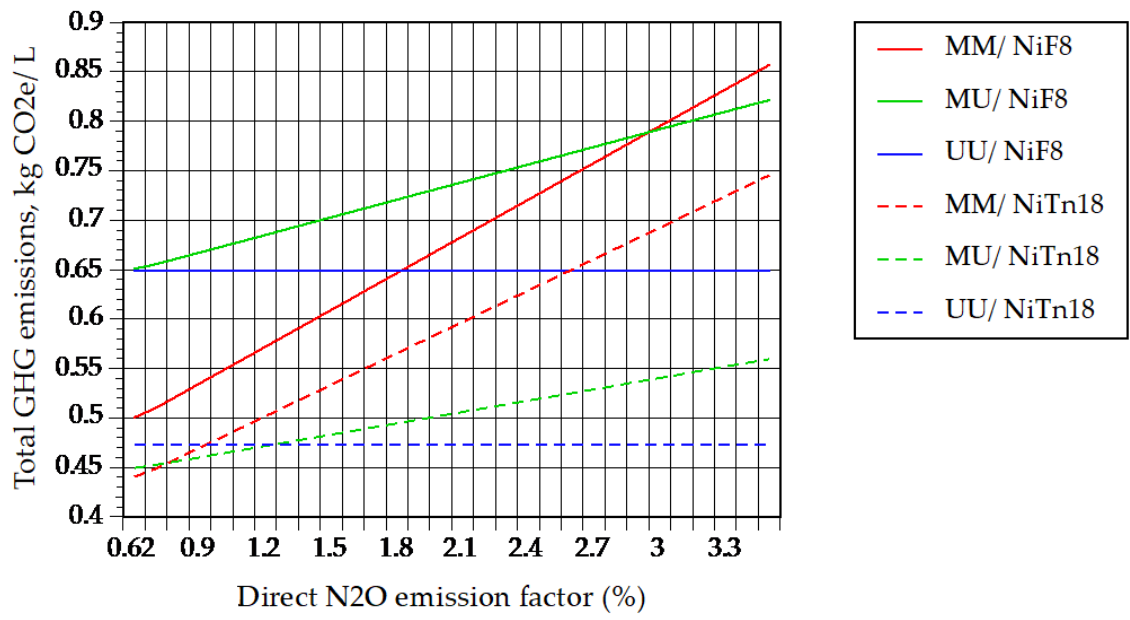

Figure 5. Sensitivity analysis of total greenhouse gas (GHG) emissions to the direct $\mathrm{N}_{2} \mathrm{O}$ emission factor from mulched soil. The emission factor is the percentage of $\mathrm{N}_{2} \mathrm{O}-\mathrm{N}$ out of the applied $\mathrm{N} ; 0.62 \%$ was the default emission factor value in the present study. MM, mulching at planting and every ratooning; $\mathrm{MU}$, mulching only at planting; $\mathrm{UU}$, untreated, i.e., no mulching at all. NiF8, a conventional cultivar; NiTn18, a cultivar characterized by improved yielding capacity and cold tolerance. 


\subsection{Comparison of Sugarcane Cultivation Systems and Other Perspectives}

The comparative LCA of sugarcane cultivation and transportation for bioethanol production in Tanegashima, Japan, showed that the cradle-to-gate energy inputs and GHG emissions from the $\mathrm{MU} / \mathrm{NiF} 8$ system were higher than those of the UU/NiF8 system (Figure 3a,b), although the differences were minor and more than offset by decreasing the number of ratoons to one or two (Figure $4 a, b$ ), as is frequently practiced in the study area [25]. In contrast, the energy inputs and GHG emissions resulting from the $\mathrm{MM} / \mathrm{NiF} 8$ system were $14 \%$ and $23 \%$ lower, respectively, as compared with the $\mathrm{UU} / \mathrm{NiF} 8$ system (Figure 3a,b), indicating that the local recommendation for mulching both at planting and ratooning is not only vital for sugarcane growth but also effective in reducing the required amount of energy and the corresponding GHG emissions from the entire process of sugarcane production. Only a small percentage ratoons are mulched in the region ( $15 \%$ of the sugarcane fields were mulched for ratoons [11]), so it is likely that the local recommendation for mulching is perceived as too costly for producers to implement without any support. Policymakers might need to create an economic incentive for producers so that they would more readily accept the local recommendation for mulching and thereby reduce both energy inputs and GHG emissions per unit of ethanol produced. To help policymakers design an effective policy measure, efforts have been made to extend this type of LCA to link it with other socio-economic modelling [42,43]. The cold-tolerant genotype (NiTn18) improved ethanol yields considerably as compared with NiF8 (Figure 2), which also reduced the energy inputs and GHG emissions for ethanol production (Figure 3a,b). The improved ethanol yield was apparent with the UU and MU treatments (Figure 2). As the result, total energy inputs and total GHG emissions to produce $1 \mathrm{~L}$ of ethanol were comparable among all three mulching systems with NiTn18 (Figure 3a,b), indicating that more flexible mulching treatments might be acceptable for NiTn18. Furthermore, the energy inputs and GHG emissions resulting from the UU/NiTn18 system were $14 \%$ and $5 \%$ lower, respectively, than those of the $\mathrm{MM} / \mathrm{NiF} 8$ system (Figure 3a,b), suggesting that the handicap of sugarcane production in cold conditions could be overcome by using cold-tolerant cultivars. An attempt of obtaining traits related to excel early phase growth is often brought from wild species (Saccharum spontaneum) through breeding to overcome cold stress [26,27]. It should be noted, however, that this approach tends to be accompanied by unwelcoming traits of thinner stalks and poor defoliation [44]. The fact that NiF8 is still the most grown cultivar in Tanegashima [11] is showing the difficulty to develop an all-round cultivar that is characterized by excel early phase growth, thick stalk, and easy defoliation at once, the traits earned for by growers and sugar millers. Unlike thin stalks and poor defoliation that are hard to be controlled by cultivation techniques, one can make up for poor early phase growth to some extent by means of polyethylene mulching.

The sensitivity analysis showed that the GHG emissions from sugarcane production were sensitive to the direct $\mathrm{N}_{2} \mathrm{O}$ emission factor for mulched soil, with the parameter initially set at $0.62 \%$ (the percentage of $\mathrm{N}_{2} \mathrm{O}-\mathrm{N}$ out of the applied N) (Figure 5). The GHG emissions resulting from the MM/NiF8 system were even higher than those from the MU/NiF8 system at an emission factor of $1.8 \%$ and higher than the UU/NiF8 system when the emission factor exceeded $3.0 \%$. In their recent review of direct $\mathrm{N}_{2} \mathrm{O}$ emission from mulched soil, Steinmetz et al. [45] stated, "under oxidising conditions, increased $\mathrm{N}_{2} \mathrm{O}$ fluxes were observed predominantly during and after solarisation and disinfection measures, or when the soil was fertilised substantially with inorganic nitrogen

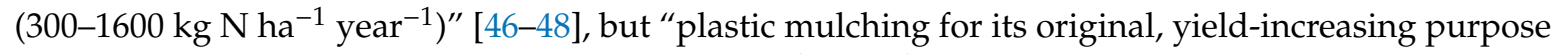
together with moderate fertilisation $\left(<180 \mathrm{~kg} \mathrm{~N} \mathrm{ha}^{-1}\right.$ year $^{-1}$ ), in contrast, mostly led to $\mathrm{N}_{2} \mathrm{O}$ emissions comparable to those of non-mulched soil" $[49,50]$. Apparently, polyethylene mulching for sugarcane production in Tanegashima, Japan, falls within the latter group. Polyethylene film is applied just after planting and/or ratooning during the cold season with moderate fertilization $\left(150 \mathrm{~kg} \mathrm{~N} \mathrm{ha}^{-1}\right.$ year $\left.{ }^{-1}\right)$ to increase yields; it is then removed before intertillage in spring [17]. Nevertheless, monitoring $\mathrm{N}_{2} \mathrm{O}$ fluxes from the mulched and non-mulched soil for sugarcane production might be needed, coupled with an uncertainty assessment of other parameters, to improve the accuracy of the comparative LCA for GHG emissions from sugarcane production with and without polyethylene mulching. Assessing 
other impact categories (e.g., endpoint indicators related to microplastics in soils) and exploring the effects of alternative material use for mulching (e.g., biodegradable plastic) warrants further research to deepen and broaden our understanding of the feasibility of sugarcane-based bioethanol production in cold conditions.

Author Contributions: Conceptualization, T.N. and S.I.; methodology, T.N., K.U. and E.F.; software, T.N. and S.I.; validation, T.N. and S.I.; formal analysis, T.N. and S.I.; data curation, K.U. and E.F.; writing-original draft preparation, T.N. and S.I.; writing-review and editing, T.N., S.I. and K.U.; visualization, T.N.; supervision, T.N. and S.I.; funding acquisition, T.N. and S.I. All authors have read and agreed to the published version of the manuscript.

Funding: This research was funded by the NARO (320c0) and the Japan Society for the Promotion of Science (Grant-in-Aid for Scientific Research C, No. 20K06267).

Acknowledgments: T.N. and S.I. are grateful to S. Ando for giving us a chance to work with K.U. and E.F.

Conflicts of Interest: The authors declare no conflict of interest. The funders had no role in the design of the study; in the collection, analyses, or interpretation of data; in the writing of the manuscript, or in the decision to publish the results.

\section{Appendix A}

Table A1. Detailed description of field experiments (Exp.).

\begin{tabular}{|c|c|c|c|c|c|c|c|c|c|}
\hline & \multirow{2}{*}{ Cultivar } & \multicolumn{6}{|c|}{ Mulching Treatment } & \multirow{2}{*}{ Rep. } & \multirow{2}{*}{ No. Plots } \\
\hline & & 2003 & 2004 & 2005 & 2006 & 2007 & 2008 & & \\
\hline \multirow[t]{7}{*}{ Exp. 1} & & $\begin{array}{l}\text { Plant } \\
\text { cane }\end{array}$ & $\begin{array}{c}1 \text { st } \\
\text { ratoon }\end{array}$ & $\begin{array}{l}\text { 2nd } \\
\text { ratoon }\end{array}$ & $\begin{array}{c}\text { 3rd } \\
\text { ratoon }\end{array}$ & & & & \multirow{7}{*}{18} \\
\hline & NiF8 & $\mathrm{M}$ & $\mathrm{M}$ & $\mathrm{M}$ & $\mathrm{M}$ & & & 3 & \\
\hline & & M & $\mathrm{U}$ & $\mathrm{U}$ & $\mathrm{U}$ & & & 3 & \\
\hline & & $\mathrm{U}$ & $\mathrm{U}$ & $\mathrm{U}$ & $\mathrm{U}$ & & & 3 & \\
\hline & NiTn18 & $\mathrm{M}$ & M & $\mathrm{M}$ & M & & & 3 & \\
\hline & & M & $\mathrm{U}$ & $\mathrm{U}$ & $\mathrm{U}$ & & & 3 & \\
\hline & & $\mathrm{U}$ & $\mathrm{U}$ & $\mathrm{U}$ & $\mathrm{U}$ & & & 3 & \\
\hline \multirow[t]{7}{*}{ Exp.2 } & & & $\begin{array}{l}\text { Plant } \\
\text { cane }\end{array}$ & $\begin{array}{c}1 \text { st } \\
\text { ratoon }\end{array}$ & $\begin{array}{l}2 \mathrm{nd} \\
\text { ratoon }\end{array}$ & $\begin{array}{l}\text { 3rd } \\
\text { ratoon }\end{array}$ & & & \multirow{8}{*}{12} \\
\hline & NiF8 & & $\mathrm{M}$ & $\mathrm{M}$ & M & M & & 2 & \\
\hline & & & M & $\mathrm{U}$ & $\mathrm{U}$ & $\mathrm{U}$ & & 2 & \\
\hline & & & $\mathrm{U}$ & $\mathrm{U}$ & $\mathrm{U}$ & $\mathrm{U}$ & & 2 & \\
\hline & NiTn18 & & M & M & M & $\mathrm{M}$ & & 2 & \\
\hline & & & M & $\mathrm{U}$ & $\mathrm{U}$ & $\mathrm{U}$ & & 2 & \\
\hline & & & $\mathrm{U}$ & $\mathrm{U}$ & $\mathrm{U}$ & $\mathrm{U}$ & & 2 & \\
\hline \multirow[t]{7}{*}{ Exp.3 } & & & & $\begin{array}{l}\text { Plant } \\
\text { cane }\end{array}$ & $\begin{array}{c}1 \text { st } \\
\text { ratoon }\end{array}$ & $\begin{array}{l}\text { 2nd } \\
\text { ratoon }\end{array}$ & $\begin{array}{l}\text { 3rd } \\
\text { ratoon }\end{array}$ & & \\
\hline & NiF8 & & & M & $\mathrm{M}$ & $\mathrm{M}$ & M & 2 & \multirow{6}{*}{12} \\
\hline & & & & M & $\mathrm{U}$ & $\mathrm{U}$ & $\mathrm{U}$ & 2 & \\
\hline & & & & $\mathrm{U}$ & $\mathrm{U}$ & $\mathrm{U}$ & $\mathrm{U}$ & 2 & \\
\hline & NiTn18 & & & $\mathrm{M}$ & $\mathrm{M}$ & $\mathrm{M}$ & $\mathrm{M}$ & 2 & \\
\hline & & & & M & $\mathrm{U}$ & $\mathrm{U}$ & $\mathrm{U}$ & 2 & \\
\hline & & & & $\mathrm{U}$ & $\mathrm{U}$ & $\mathrm{U}$ & $\mathrm{U}$ & 2 & \\
\hline
\end{tabular}

$\mathrm{NiF8}$, a conventional cultivar; NiTn18, a new cultivar characterized by improved yielding capacity and cold tolerance. $\mathrm{M}$, mulching treatment; $\mathrm{U}$, untreated (no mulching). 
Table A2. Date of planting $(\mathrm{P})$, harvesting $(\mathrm{H})$ and ratooning $(\mathrm{R})$ in field experiments (Exp.).

\begin{tabular}{cccccccccc}
\hline & \multicolumn{2}{c}{ Plant Cane } & \multicolumn{2}{c}{ 1st Ratoon } & \multicolumn{2}{c}{ 2nd Ratoon } & \multicolumn{2}{c}{ 3rd Ratoon } \\
\cline { 2 - 10 } & $\mathbf{P}$ & $\mathbf{H}$ & $\mathbf{R}$ & $\mathbf{H}$ & $\mathbf{R}$ & $\mathbf{H}$ & $\mathbf{R}$ & $\mathbf{H}$ \\
\hline \multirow{2}{*}{ Exp.1 } & 31 March & 21 & 17 & 20 & 21 & 16 & 14 & 19 \\
& 2003 & January & February & January & February & January & February & January \\
& 25 & 2004 & 2004 & 2005 & 2005 & 2006 & 2006 & 2007 & 19 \\
Exp.2 & February & January & February & January & February & January & February & December \\
& 2004 & 2005 & 2005 & 2006 & 2006 & 2007 & 2007 & 2007 & 26 \\
Exp.3 & 9 March & 7 & February & February & February & February & 9 January & February & January \\
& 2005 & 2006 & 2006 & 2007 & 2007 & & 2008 & 2009 \\
\hline
\end{tabular}

\section{References}

1. Robertson, G.P.; Paul, E.A.; Harwood, R.R. Greenhouse gases in intensive agriculture: Contributions of individual gases to the radiative forcing of the atmosphere. Science 2000, 289, 1922-1925. [CrossRef] [PubMed]

2. Smith, P.; Bustamante, M.; Ahammad, H.; Clark, H.; Dong, H.; Elsiddig, E.A.; Haberl, H.; Harper, R.; House, J.; Jafari, M.; et al. Agriculture, forestry and other land use (AFOLU). In Climate Change 2014: Mitigation of Climate Change. Contribution of Working Group III to the Fifth Assessment Report of the Intergovernmental Panel on Climate Change; Edenhofer, O., Pichs-Madruga, R., Sokona, Y., Farahani, E., Kadner, S., Seyboth, K., Adler, A., Baum, I., Brunner, S., Eickemeier, P., et al., Eds.; Cambridge University Press: Cambridge, UK; New York, NY, USA, 2014; pp. 811-922.

3. Bakker, H. Sugar Cane Cultivation and Management; Kluwer Academic/Plenum Publishers: New York, NY, USA, 1999; pp. 1-679.

4. Ahorsu, R.; Medina, F.; Constantí, M. Significance and challenges of biomass as a suitable feedstock for bioenergy and biochemical production: A review. Energies 2018, 11, 3366. [CrossRef]

5. Cardona, C.A.; Sanchez, O.J. Fuel ethanol production: Process design trends and integration opportunities. Bioresour. Technol. 2007, 98, 2415-2457. [CrossRef] [PubMed]

6. Ministry of Agriculture, Forestry and Fisheries, Annual Report on Food, Agriculture and Rural Areas in Japan FY. 2007. Available online: www.maff.go.jp/e/data/publish/an_archive.html (accessed on 29 June 2020).

7. Goldemberg, J.; Coelho, S.T.; Guardabassi, P. The sustainability of ethanol production from sugarcane. Energy Policy 2008, 36, 2086-2097. [CrossRef]

8. Hira, A.; de Oliveira, L.G. No substitute for oil? How Brazil developed its ethanol industry. Energy Policy 2009, 37, 2450-2456. [CrossRef]

9. Matsuoka, M. Sugarcane cultivation and sugar industry in Japan. Sugar Tech 2006, 8, 3-9. [CrossRef]

10. Japan Meteorological Agency (JMA). Weather Information of the Tanegashima Island During 1981-2010. Available online: www.data.jma.go.jp/obd/stats/etrn (accessed on 29 June 2020). (In Japanese)

11. Kagoshima Prefecture, Agriculture, Forestry \& Fisheries Department. Report of Sugarcane and Sugar Production; Kagoshima Prefecture, Agriculture, Forestry \& Fisheries Department: Kagoshima, Japan, 2010. (In Japanese)

12. Ebata, M.; Aihoshi, K.; Nakama, N.; Shimowada, K.; Urasaki, K. Studies on the polyethylene-film cover and mulching for sugarcane (I) The effects of mulching and planting date on the spring planting of sugarcane. Kyushu Agric. Res. 1969, 31, 73-74. (In Japanese)

13. Millard, E.W. Plastic mulching of sugarcane. SASTA Proc. 1974, 48, 53-57.

14. Yasuniwa, M.; Machida, M.; Uezono, T.; Kouzuma, M.; Izumi, S.; Kamikado, T.; Misono, A. The development of sugarcane cultivation by ratooning in Tanegashima island. Bull. Kagoshima Pref. Agri. Exp. Stat. 1991, 19, 1-16. (In Japanese)

15. Kasirajan, S.; Ngouajio, M. Polyethylene and biodegradable mulches for agricultural applications: A review. Agron. Sustain. Dev. 2012, 32, 501-529. [CrossRef]

16. Li, Y.-R.; Yang, L.-T. Sugarcane agriculture and sugar industry in China. Sugar Tech 2015, 17, 1-8. [CrossRef]

17. Sugar Industry Association of Kagoshima Prefecture. Guideline for Sugarcane Cultivation in Kagoshima Prefecture; Sugar Industry Association of Kagoshima Prefecture: Kagoshima, Japan, 2010. (In Japanese) 
18. International Organization for Standardization (ISO). ISO 14040, Environmental Management-Life Cycle Assessment_-Principles and Framework; ISO: Geneva, Switzerland, 2006; pp. 1-20.

19. International Organization for Standardization (ISO). ISO 14044, Environmental Management_Life Cycle Assessment-Requirements and Guidelines; ISO: Geneva, Switzerland, 2006; pp. 1-44.

20. Goldemberg, J. Ethanol for a sustainable energy future. Science 2007, 315, 808-810. [CrossRef] [PubMed]

21. Von Blottnitz, H.; Curran, M.A. A review of assessments conducted on bioethanol as a transportation fuel from a net energy, greenhouse gas, and environmental life cycle perspective. J. Clean. Prod. 2007, 15, 607-619. [CrossRef]

22. Food and Agriculture Organization of the United Nations (FAO). The State of Food and Agriculture 2008: Biofuels: Prospects, Risks and Opportunities; FAO: Rome, Italy, 2008; Volume 38, pp. 1-128.

23. Macedo, I.C.; Seabra, J.E.A.; Silva, J.E.A.R. Green house gases emissions in the production and use of ethanol from sugarcane in Brazil: The 2005/2006 averages and a prediction for 2020. Biomass Bioenergy 2008, 32, 582-595. [CrossRef]

24. Nguyen, T.L.T.; Gheewala, S.H.; Bonnet, S. Life cycle assessment of fuel ethanol from cane molasses in Thailand. Int. J. Life Cycle Assess. 2008, 13, 301-311. [CrossRef]

25. Nakashima, T.; Ishikawa, S. Energy inputs and greenhouse gas emissions associated with small-scale farmer sugarcane cropping systems and subsequent bioethanol production in Japan. NJAS Wagening. J. Life Sci. 2016, 76, 43-53. [CrossRef]

26. Lam, E.; Shine, J., Jr.; Da Silva, J.; Lawton, M.; Bonos, S.; Calvino, M.; Carrer, H.; Silva-Filho, M.C.; Glynn, N.; Helsel, Z.; et al. Improving sugarcane for biofuel: Engineering for an even better feedstock. GCB Bioenergy 2009, 1, 251-255. [CrossRef]

27. Waclawovsky, A.J.; Sato, P.M.; Lembke, C.G.; Moore, P.H.; Souza, G.M. Sugarcane for bioenergy production: An assessment of yield and regulation of sucrose content. Plant Biotechnol. J. 2010, 8, 263-276. [CrossRef]

28. Terajima, Y.; Sugimoto, A.; Matsuoka, M.; Ujihara, K.; Sakaigaichi, T.; Fukuhara, S.; Maeda, H.; Katsuta, Y.; Oka, M.; Shimoda, S.; et al. New sugarcane cultivar NiTn18 with excellent ratooning ability in mulch-free cultivation. Bull. Natl. Agric. Res. Ctr. Kyushu Okinawa Reg. 2010, 54, $23-41$.

29. Agriculture, Forestry and Fisheries Research Council. Development of Bio-Energy Crops for Domestic Production and Low-Input Cultivation Technologies; The Ministry of Agriculture, Forestry and Fisheries: Tokyo, Japan, 2014; Volume 498, pp. 1-258. (In Japanese)

30. Wortmann, C.S.; Liska, A.J.; Ferguson, R.B.; Lyon, D.J.; Klein, R.N.; Dweikat, I. Dryland performance of sweet sorghum and grain crops for biofuel in Nebraska. Agron. J. 2010, 102, 319-326. [CrossRef]

31. Zhao, Y.L.; Steinberger, Y.; Shi, M.; Han, L.P.; Xie, G.H. Changes in stem composition and harvested produce of sweet sorghum during the period from maturity to a sequence of delayed harvest dates. Biomass Bioenergy 2012, 39, 261-273. [CrossRef]

32. GHG Protocol, Inventory Database for Environmental Analysis (IDEA). Available online: www.ghgprotocol. org/third-party-databases/IDEA (accessed on 29 June 2020).

33. Inventory Database for Environmental Analysis (IDEA). Available online: http://idea-lca.jp (accessed on 29 June 2020).

34. Ogino, A.; Orito, H.; Shimada, K.; Hirooka, H. Evaluating environmental impacts of the Japanese beef cow-calf system by the life cycle assessment method. Anim. Sci. J. 2007, 78, 424-432. [CrossRef]

35. Ogino, A.; Osada, T.; Takada, R.; Takagi, T.; Tsujimoto, S.; Tonoue, T.; Matsui, D.; Katsumata, M.; Yamashita, T.; Tanaka, Y. Life cycle assessment of Japanese pig farming using low-protein diet supplemented with amino acids. Soil Sci. Plant Nutr. 2013, 59, 107-118. [CrossRef]

36. Center for Environmental Information Service. Guidebook for Life Cycle Inventory Analysis; The Chemical Daily Co. Ltd.: Tokyo, Japan, 1998. (In Japanese)

37. De Klein, C.; Novoa, R.S.; Ogle, S.; Smith, K.A.; Rochette, P.; Wirth, T.C.; McConkey, B.G.; Mosier, A.; Rypdal, K.; Walsh, M.; et al. $\mathrm{N}_{2} \mathrm{O}$ emissions from managed soils, and $\mathrm{CO}_{2}$ emissions from lime and urea application. In IPCC Guidelines for National Greenhouse Gas Inventories, Prepared by the National Greenhouse Gas Inventories Programme 4; Eggleston, S., Buendia, L., Miwa, K., Ngara, T., Tanabe, K., Eds.; IPCC: Kanagawa, Japan, 2006; Chapter 11; pp. 1-54.

38. Akiyama, H.; Yan, X.; Yagi, K. Estimations of emission factors for fertilizer-induced direct $\mathrm{N}_{2} \mathrm{O}$ emissions from agricultural soils in Japan: Summary of available data. Soil Sci. Plant Nutr. 2006, 52, 774-787. [CrossRef] 
39. Greenhouse Gas Inventory Office of Japan. National Greenhouse Gas Inventory Report of Japan 2017; Ministry of the Environment: Tokyo, Japan, 2017; Available online: www-gio.nies.go.jp/aboutghg/nir/nir-archives_e.html (accessed on 29 June 2020).

40. Forster, P.; Ramaswamy, V.; Artaxo, P.; Berntsen, T.; Betts, R.; Fahey, D.W.; Haywood, J.; Lean, J.; Lowe, D.C.; Myhre, G.; et al. Changes in atmospheric constituents and in radiative forcing. In Climate Change 2007: The Physical Science Basis. Contribution of Working Group I to the Fourth Assessment Report of the Intergovernmental Panel on Climate Change; Solomon, S., Qin, D., Manning, M., Chen, Z., Marquis, M., Averyt, K.B., Tignor, M., Miller, H.L., Eds.; Cambridge University Press: Cambridge, UK; New York, NY, USA, 2007; Chapter 2, pp. 130-234.

41. Bruce, T.J.A.; Matthes, M.C.; Napier, J.A.; Pickett, J.A. Stressful memories of plants: Evidence and possible mechanisms. Plant Sci. 2007, 173, 603-608. [CrossRef]

42. Nakashima, T. Life cycle assessment integrated into positive mathematical programming: A conceptual model for analyzing area-based farming policy. JARQ Jpn. Agric. Res. Q. 2010, 44, 301-310. [CrossRef]

43. Nakashima, T.; Ishikawa, S. Linking life cycle assessment to bioeconomic modelling with positive mathematical programming: An alternative approach to calibration. J. Clean. Prod. 2017, 167, 875-884. [CrossRef]

44. Irvine, J.E. Identification of cold tolerance in Saccharum and related genera through refrigerated freeze screening. Proc. Int. Soc. Sugarcane Technol. 1978, 16, 147-156.

45. Steinmetz, Z.; Wollmann, C.; Schaefer, M.; Buchmann, C.; David, J.; Tröger, J.; Muñoz, K.; Frör, O.; Schaumann, G.E. Plastic mulching in agriculture. Trading short-term agronomic benefits for long-term soil degradation? Sci. Total Environ. 2016, 550, 690-705. [CrossRef]

46. Arriaga, H.; Núñez-Zofio, M.; Larregla, S.; Merino, P. Gaseous emissions from soil biodisinfestation by animal manure on a greenhouse pepper crop. Crop. Prot. 2011, 30, 412-419. [CrossRef]

47. Nishimura, S.; Komada, M.; Takebe, M.; Yonemura, S.; Kato, N. Nitrous oxide evolved from soil covered with plastic mulch film in horticultural field. Biol. Fertil. Soils 2012, 48, 787-795. [CrossRef]

48. Cuello, J.P.; Hwang, H.Y.; Gutierrez, J.; Kim, S.Y.; Kim, P.J. Impact of plastic film mulching on increasing greenhouse gas emissions in temperate upland soil during maize cultivation. Appl. Soil Ecol. 2015, 91, 48-57. [CrossRef]

49. Berger, S.; Kim, Y.; Kettering, J.; Gebauer, G. Plastic mulching in agriculture-Friend or foe of $\mathrm{N}_{2} \mathrm{O}$ emissions? Agric. Ecosyst. Environ. 2013, 167, 43-51. [CrossRef]

50. Li, Z.; Zhang, R.; Wang, X.; Chen, F.; Lai, D.; Tian, C. Effects of plastic film mulching with drip irrigation on $\mathrm{N}_{2} \mathrm{O}$ and $\mathrm{CH}_{4}$ emissions from cotton fields in arid land. J. Agric. Sci. 2014, 152, 534-542. [CrossRef] 